\title{
Dermatites digitais em bovinos ${ }^{*}$
}

\section{CLÁUDIO ESTÊVÃO FARIAS DA CRUZ}

\author{
David Driemeier (Orientador - UFRGS)
}

Banca: Cláudio Severo Lombardo de Barros (UFSM), Marisa Ribeiro de Itapema Cardoso (UFRGS), José Renato Junqueira Borges (UnB)

Na primeira etapa deste estudo descrevem-se a ocorrência da dermatite digital no sul do Brasil, as condições ambientais nas quais tem sido observada e o aspecto macroscópico das lesões. O segundo artigo incluso neste trabalho aborda aspectos comparativos em diferentes lesões da pele digital de bovinos, cujos fragmentos embebidos em parafina foram seccionados e corados com Warthin-Starry, hematoxilina-eosina e, ocasionalmente, Grocott's methenamine silver. Amostras representativas dessas lesões foram testadas com soros antibacerianos, através do método immunoistoquímico da peroxidase, para identificação específica de bactérias. Os microorganismos observados nas lâminas coradas com prata foram classificados em quatro categorias principais. Enquanto espiroquetas foram os organismos mais prevalentes, outros elementos bacilares e esféricos estiveram também presentes em muitos cortes. Os testes immunoistoquímicos demonstraram que aproximadamente 80,46 e $41 \%$ das amostras de dermatites digitais e interdigitais marcaram positivamente quando coradas com anticorpos policlonais contra Treponema pallidum, Campylobacter jejuni e Fusobacterium necrophorum, respectivamente. Além disso, um organismo ramificado e filamentoso (presumivelmente um actinomiceto) esteve consistentemente presente nas lâminas de amostras de lesões interdigitais leves. A associação destes organismos com as populações microbianas mistas presentes nessas dermatites é indicativa de seu envolvimento na formação das lesões.

Descritores: bovino, dermatites digitais, imunoistoquímica, Treponema, Campylobacter, Fusobacterium. 


\title{
Bovine digital dermatitis**
}

\section{CLÁUDIO ESTÊVÃO FARIAS DA CRUZ}

\author{
David Driemeier (Adviser - UFRGS)
}

Committee: Cláudio Severo Lombardo de Barros (UFSM), Marisa Ribeiro de Itapema Cardoso (UFRGS), José Renato Junqueira Borges (UnB)

The first article of this study reports the occurrence of digital dermatitis in dairy cattle in southern Brazil, describes the environmental conditions in which it has been observed and the clinical appearance of the lesions. The second paper concerns a comparative study on several bovine digital skin lesions, from which paraffin-embedded fragments were sectioned and stained with Warthin-Starry, hematoxylin-eosin, and occasionally Grocott's methenamine silver. Representative samples were additionally screened with antibacterial sera associated with the peroxidase immunohistochemical technique for specific bacterial identification. Microorganisms observed in the silver-stained sections were classified into four major morphological types. While spirochetes were the most prevalent organisms, additional bacillary and coccoid elements were also present in most sections. Immunohistochemical probing demonstrated that approximately 80, 46 and $41 \%$ of the digital and interdigital dermatitis sections stained positively with polyclonal antisera to Treponema pallidum, Campylobacter jejuni, and Fusobacterium necrophorum, respectively. Moreover, an unidentified branching filamentous organism (presumed to be an actinomycetes species) was consistently present in the sections of samples from mild interdigital lesions. The immunohistochemical association of these organisms with the polymicrobial communities present in those bovine digital epidermitis lesions is indicative of their involvement in the formation of these lesions and demonstrates additional evidences for their frequently reported multifactorial etiology.

Key words: bovine, digital epidermitis, immunohistochemistry, Treponema, Campylobacter, Fusobacterium. 